\title{
Supply chain relationship quality, environmental uncertainty, supply chain performance and financial performance of high-tech agribusinesses in Vietnam
}

\author{
Thi Huyen Pham ${ }^{a}$ and Thi Diep Uyen Doan ${ }^{b^{*}}$
}

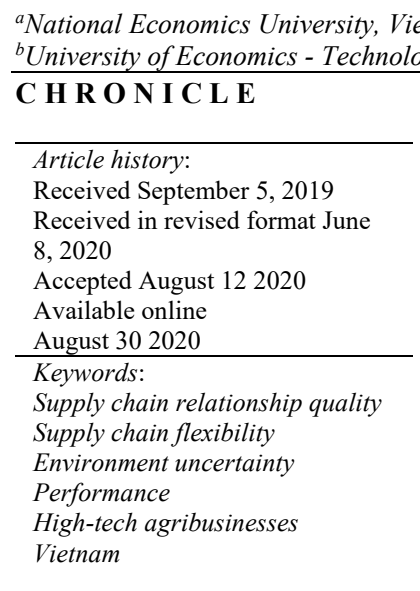
\begin{abstract}
A B S T R A C T
The objective of this article is to assess the impact of supply chain relationship quality on supply chain performance and financial performance through environment uncertainty of high-tech agricultural enterprises in Vietnam. The study conducted data analysis based on 198 agricultural firms applying high technology in high-tech agricultural group and in all of Vietnam. The results show that, agricultural enterprises applying high technology with supply chain relationship quality had a strong positive impact on supply chain performance and supply chain flexibility. In addition, supply chain performance played a significant role in financial performance. Finally, Environment uncertainty and technological innovation played a statistically significant moderate role in the relationship between supply chain relationship quality and supply chain performance. For businesses with less environment uncertainty, the relationship was stronger and vice versa. The bigger the technology innovation, the stronger there the relationship.
\end{abstract}

(C) 2020 by the authors; license Growing Science, Canada.

\section{Introduction}

Vietnam is a developing country and agriculture still plays an important role in today's economy. However, Vietnam's agricultural production is facing many challenges: The population increases, so the demand for food is constantly increasing; The area of agricultural land is shrinking due to urbanization, which requires increasing agricultural productivity to meet food security; Climate change is taking place strongly, creating great pressure on agriculture; The process of international integration requires higher quality of agricultural products. Therefore, hi-tech agricultural development is an indispensable impulse for the development of Vietnam's agriculture. In the national economy, agriculture plays a very important role. According to the General Statistics Office, the Ministry of Planning and Investment, the workforce in agriculture and rural areas accounts for $40 \%$ of Vietnam's labor force. The agricultural development policy was concerned by the Party and the State many years ago, due to the lack of systematic implementation, lack of uniformity, and low investment resources for agriculture. However, Vietnam's agricultural development has not achieved as expected. In general, agriculture plays a great role not only in ensuring food supply for the society, but also contributing to economic growth as one of three important economic sectors in most important parts of the country. However, traditional agriculture depends on natural conditions, exploits inputs in land, labor, and water, and is not under sustainable condition. Therefore, it is necessary to deal with building modern agriculture and freeing up the labor force in agriculture to work in other non-agricultural fields to industrialize and modernize the country.

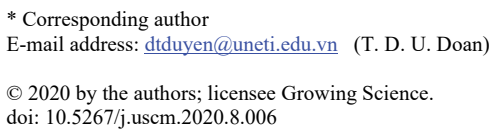


A system from production to harvesting, storage, processing and bringing products to the market is not really synchronous, farmers still bear many risks in weather, market, disease and productivity. Low income leads to the farmers' income and has not been improved as much as expected. On the other hand, the rapid urbanization process is changing the behavior of using food in the direction of using plant and animal proteins, fruits and packaged products.

The issue of food safety and hygiene is increasingly demanding, but traditional agriculture is difficult to meet. Over time, the agriculture has appeared a supply chain of products from farm to table that requires good cold storage technology and block chain technology but in general, it still cannot meet the requirements.

Developing high-tech agriculture in association with sustainable development is Vietnam's top priority. High-tech agriculture is an agriculture that is applied in combination with new and advanced technologies to produce in order to improve efficiency, create a breakthrough in productivity and quality of agricultural products, as well as reaching a high level of society and ensuring sustainable agricultural development. High technology is integrated in high-tech agriculture, including: agricultural industrialization (mechanization of stages of production, harvesting, preliminary processing, processing ...), automation information technology, new materials technology, biotechnology; high yield and quality crops and animals, advanced farming processes and organic farming for high economic efficiency per unit of production. Hightech agricultural zones focus on the application of high-tech research and development achievements to the agricultural sector to perform different tasks such as selecting, creating and multiplying plants and animals, productivity, high quality services, cultivating and breeding with high efficiency, creating materials, machines and equipment used in agriculture, preserving and processing agricultural products, developing agricultural enterprises with high technology application and developing high-tech services for agriculture. High technology in agriculture is understood as reasonably applying the most advanced techniques in selecting and breeding new plant and animal varieties, taking care and nurturing plants and animals with automatic equipment, remote control, micro-organic fertilizer processing for crops, animal feed, poultry, aquatic products, veterinary drugs, plant protection products, automatic technology in irrigation, technology for processing products livestock products, plants and waste treatment to protect the environment. Here, biotechnology plays a primary role. Hightech agricultural area is a concentrated agricultural production area that applies achievements of high-tech research and development to the agricultural sector to perform the task of producing one or several agricultural products, commodity and export strategies based on the results of high yield and quality of plant breeding and breeding; prevention and eliminating of epidemics, cultivating and breeding with high efficiency, use of materials, machinery and modern equipment in agriculture; preserving and processing agricultural products and high-tech services in agricultural production.

The empirical study of supply chain relationships (SC) is mainly concerned with the nature of processes and relationships rather than the effect of supply chain relationship quality on performance (Styles \& Ambler, 2000). Therefore, previous studies have mainly focused on the interactions between aspects of the relationship in the supply chain such as trust, cooperation, and adaptability rather than concerned with relationship quality. supply chain and its impact on business performance.

In this study, we use contingency theory, predictive theory provides us with a useful theoretical framework to analyze assumptions in the context of high-tech agribusinesses in Vietnam.

The relationship between suppy chain relationship quality and supply chain performance and the moderate role of the Environment uncertainty has been studied by many authors, however in the context of high-tech agriculture with a high dependence on uncertain conditions, there are very few researchers interested, especially in the field of agriculture. The goal of the article is to evaluate the relationship between supply chain relationship quality, supply chain performance, financial performance under the environment uncertainty.

The layout of the article in addition to the introduction includes: Research overview, research methods, research results and conclusions.

\section{Literature review}

\subsection{Supply chain relationship quality}

Supply chain relationship quality has been used by previous researchers and a variety of relevant theories explain the nature of the relationships in the supply chain. Some fundamental theories and concepts used in this research topic include: Transaction costs, political economy, socioeconomic and resource-based theory (Robicheaux \& Coleman, 1994). The essence of transaction cost theory is that the economic contracts of the firm both inside and outside the firm incur related costs. These costs include pre-drafting the contract to negotiation costs and after-sales and warranty costs, all arising in these activities are resolved by arbitration. From the point of view of political economy, the social system consists of the interactive sets of economic and socio-political forces that influence the behavior and activities of the collective. The primary aim of the political economy perspective is to provide evidence to better explain supply chain relationships. At the same time, this theory explains the behavior of members and units in the supply chain relationship, assessing the difficulty and the context that affects the behavior of members in the supply chain relationship. 
The socioeconomic theory argues that economic goals and activities are directly tied to the socially oriented structure (Granovetter, 1992). According to this theory, socioeconomic frameworks are the simplification of human behavior and economic institutions. For example, from an economic point of view, self-interested behavior is the main driver of human behavior and attitudes. But according to sociological theory, the moral norms determine the individual's behavior. Socioeconomic theory also presents networks of firms and attempts to explain long-run relationships as interrelated relationships that provide firm value and advantage (Uzzi, 1997).

\subsection{Supply chain performance}

Research on the impact of supply chain relationships, supply chain relationship quality on business performance has been concerned by many researchers. Previous studies of supply chain performance can be either qualitative or quantitative. Studies show many definitions as well as measures the supply chain performance. Supply chain performance can be measured by economic efficiency, environmental efficiency or social efficiency. Examples are cost reduction efficiency, waste reduction efficiency and negative environmental impacts. Another theoretical flow that measures the impact of the quality of supply chain relationships has a positive impact on firm business performance. For example, according to Narasimahan and Jayaram (1998), there is a strong positive relationship between supply chain relationship quality and supply chain performance. Neely et al. (1991) define performance measurement as the process of measuring the effectiveness and efficiency of an action. According to Shen et al. (2013), performance metrics were noticed in the agrofood chain and various performance measurements were used. In marketing documentation and supply chain management, supply chain performance is measured through various methods such as cost-based activity, balance scorecard, economic value added, multi-analysis. criteria, life cycle analysis, data packaging analysis and supply chain performance reference model.

\subsection{Environment uncertainty}

Uncertainty refers to external uncertainties and the degree of uncertainty in the business environment that can occur at any point in the global supply chain network and can lead to the organization's inability to understand, estimate, and understand how the environment might change, the potential impact of the changes, and whether the organization's response to those changes can be successful. Environment uncertainty is characterized by continuous changes in technology, changes in consumer tastes, fluctuations in supply and demand of products and raw materials, even changes in the ecological environment such as earthquakes and volcanoes cause business losses. Such unexpected changes require businesses to develop a good supply chain network called supply chain relationship quality, thereby creating a symbiosis and sharing risks in the business process of the business. especially businesses applying high technology in the agricultural sector.

Environmental uncertainty is multidimensional, so firms often face a lot of environmental uncertainty at the same time (Huang et al., 2014). Uncertainty in a supply chain can take many forms, for example: uncertainty about supplier reliability, competitor actions, or product quality (Stevenson \& Spring, 2007). Simangunsong, Hendry, \& Stevenson (2011) report that although there have been studies on factors that create supply chain uncertainty, such as internal production processes, supply side processes or demand-side issues, but still many other factors that influence the uncertainty have yet to be explored. In addition, since the supply chain involves partnerships between different organizations, environmental uncertainty can affect the relationship between the quality of the partnership and the performance of the supply chain. Davis (1993) argues that there are three dimensions in Environment uncertainty: demand uncertainty, supply uncertainty and technological uncertainty. Many researchers have studied uncertainty as an important factor influencing supply chain performance and performance (Bhatnagar \& Sohal 2005). According to Miller (1993), uncertainty refers to the unpredictability of the environmental or organizational variables that affect a firm's performance. Carter et al. (2015) reported that supply chain uncertainty can occur at many levels, including those of individual decision-makers, functional departments, and ultimately the supply chain. Throughout the supply chain, agents are faced with various sources of uncertainty that can be exogenous, endogenous, or both (Chaudhuri et al., 2014). According to Prater (2005), Lee et al. ( 2012) and Lee (2002), supply chain uncertainty has been widely recognized as a problem in the supply chain. Uncertainty in the supply chain can cause delays, lead to bottlenecks, and can hinder the operation of the entire supply chain. The document argues that it is important to consider uncertainties in order to achieve operational efficiencies and smooth operations in all supply chain links as uncertainty cannot be avoided. Supply chain uncertainties relate to supply uncertainty (Chaudhuri et al. 2014), demand uncertainty (Thongrattana \& Jie 2009; Patil et al. 2012), process uncertainty (Patil et al. 2012), uncertainty control and planning (Thongrattana \& Jie 2009), competitor uncertainty (Thongrattana \& Jie 2009), government uncertainty (Thongrattana \& Jie 2009), and climatic uncertainty (Kleindorfer \& Saad 2005; Thongrattana \& Jie 2009).

\subsection{Technological innovation}

Technological innovation is the replacement of a major part or the whole of an existing technology with a more advanced, more efficient technology. Technological innovation can aim to increase productivity, quality and efficiency of the production process or perhaps to create a new product or service to serve the market.

Technological innovation can mean introducing or applying completely new technologies that are not available in the technology market or fundamentally changing existing technologies. 
Technology innovation activities include the following two basic contents:

- Product innovation: Creating a completely new product, or improving traditional products of your company and creating a new difficult product. Often, we need a large amount of costs to create facilities for this activity.

Manufacturing process innovation: Technological progress for developing countries is focused mainly on improving the efficiency of technological processes. This improvement allows for increased productivity of workers. This is reflected in the shift of production process improvement results to the right of the supply curve, reflecting the ability to improve production capacity.

\subsection{Supply chain flexibility}

Flexibility can be defined as the ability to meet an increasing number of customer expectations without wasting time or cost, to compensate for changes in the environment and keep a competitive advantage. One strategy to achieve and keep a competitive advantage in a dynamic environment is to create an entire organization that is flexible not only with production capacity but also with raw material supplier linkages (Stevenson \& Spring, 2007). In today's business environment, competition is no longer between companies, but supply chains that compete with other supply chains (Economic, 2007; Karami et al., 2014).

In environments of high uncertainty, companies should focus on flexibility (Merschmann \& Thonemann, 2011) as it allows companies to adapt to unforeseen technological and market changes (Wang et al., 2011). In addition, the components of flexibility vary from one supply chain to another (Stevenson \& Spring, 2007). The current highly competitive production environment is characterized by increasingly sophisticated consumers who require customized products and short lead times. Consequently, many companies that previously relied on winning orders through standardized low-cost manufacturing have to become more flexible to compete with other competitors (Stevenson \& Spring, 2007).

\subsection{Financial performance}

Various researchers have tried to evaluate a company's performance in different ways, but most of the performance metrics so far have been a combination of the performance aspects and finance. Financial aspects should include profitability, return on investment, sales growth, business efficiency and performance. Min and Galle (2001) measured business performance in terms of availability, variety of products / services offered, timeliness, profitability and growth. Tang (2006) used product value, customer loyalty, market value, and financial performance to measure business performance. Li et al. (2006) uses market share, return on investment, growth in market share and sales, growth in return on investment, return on revenue and overall competitive position to measure the performance of organization. Li et al. (2006) combine operational and financial aspects to define the operational structure of the business.

\section{Research method}

\subsection{Research sample}

Recognizing the importance of high-tech agriculture, on January 29, 2010, the Prime Minister issued Decision No. 176 / QD-TTg approved the Scheme on agricultural development with high technology application up to 2020. In order to realize the Project, on February 17, 2012, the Prime Minister issued Decision No. 1895 / QD-TTg approved the Program for hitech applied agricultural development under the National Program for Development in order to contribute to promot the development and construction of modern agriculture, large commodity production with high productivity, quality, efficiency and competitiveness.

Implementing the above decision, the provinces and cities in Vietnam have been actively promoting the application of high technology in agricultural production. By June 2017, the country had 29 hi-tech agricultural zones, including 3 high-tech agricultural zones approved by the Government in Hau Giang, Phu Yen and Bac Lieu provinces, and the agricultural technology zones. The rest is established by the provincial people's committee.

Although it has just been implemented in a short time, there are no statistics, but the promotion of high-tech agriculture in recent years has brought about encouraging results. During the period of 2015-2019 alone, nearly 1,000 new plant varieties have been researched and created, so the rate of the country's crop area using new varieties is quite high: rice over $90 \%$, maize $80 \%$, sugarcane $60 \%$ and $100 \%$ thing. By 2018 , the whole country had 623 communes using net houses, greenhouses and membrane houses to grow seedlings, accounting for $3.6 \%$ of the total number of communes in the country with an area of 5,897.5 ha, accounting for $0.07 \%$ of the total area. area of annual crop land and aquaculture land. Some provinces applying high technology to agricultural production have brought superior results compared to traditional production. In Lam Dong, the high-class vegetable production model has turnover of 500 million VND / ha / year; hydroponic vegetables from 8-9 billion VND / ha / year; flowers reached 1.2 billion VND / ha / year, 20-30 times higher than before contributing to the average production value of the province to 150 million / ha / year and now the value of High-tech agricultural production accounts for $30 \%$ of the total agricultural production value of the province. In Ho Chi Minh City, the model of growing high-tech vegetables in a net-house with revenue from 120 million VND to 150 million VND / ha, 2-3 times higher than traditional cultivation. In Hanoi, Ba Ria - Vung Tau, Vinh Phuc with industrial-scale seed production, pig and chicken 
production model with Japanese technology, the income is 2 times higher for the producer compared with traditional production. Bac Lieu province with greenhouse shrimp farming model has helped farmers control diseases, shrimp grow and develop quickly, bringing high efficiency, stability and sustainability.

For hi-tech agricultural regions, based on the prescribed criteria, there are 5 agricultural regions with high-tech application for intensive farming of shrimp, flowers, rice and banana. Regarding the number of enterprises, up to now, 40 high-tech enterprises have been granted valid certificates, including: 12 enterprises applying high technology in the field of crop production; 19 enterprises applying high technology in the fisheries sector; 9 enterprises applying high technology in the field of animal husbandry. There are also 168 organizations that apply high technology but have not been certified.

To test research hypotheses, we conducted direct interview research and collected data from all 208 agricultural enterprises applying high technology in production, including agricultural enterprises applying high technology certification and not yet certified. During 3 months of direct data collection, using emailing, we collected a full 208 survey forms. However, in the process of reviewing and filtering the data, only 198 valid survey forms remained, eligible to be included in data analysis.

\subsection{Research models}

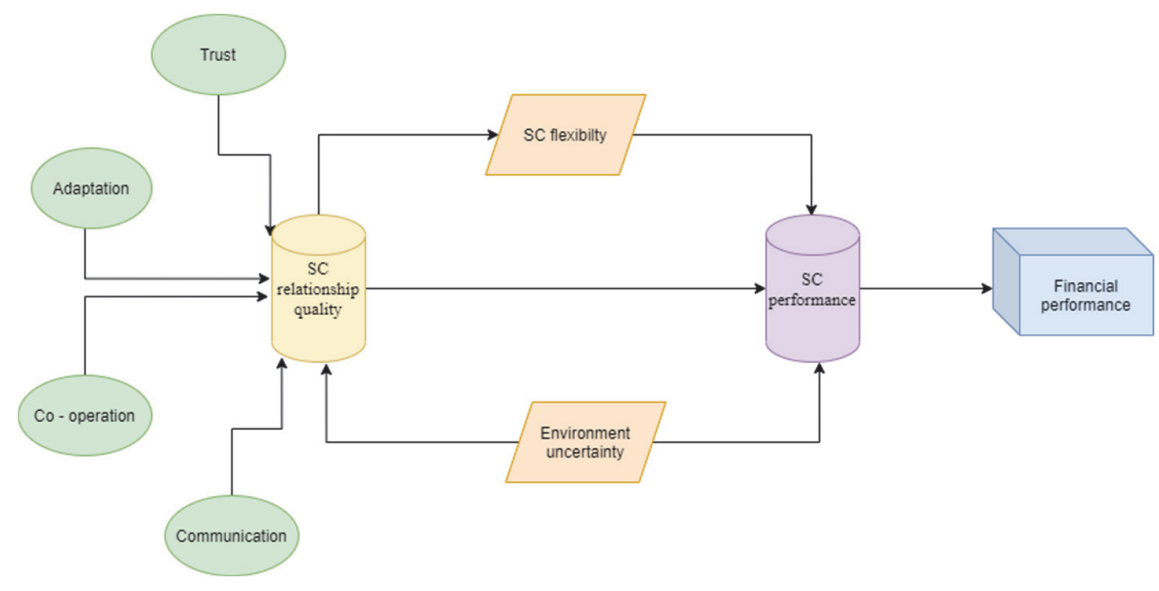

Fig. 1. Research model

Supply chain relationship quality: The second order - factor variable is composed of 4 variables the first order factor: Trust, Adatation, Co - operation, Communication. Measured by 16 items developed from Fynes et al. (2004). The scales are measured using the 5-point Likert scale from 1 being totally disagree to 5 being totally in agreement.

Supply chain flexibility: The flexibility of the supply chain of high-tech agribusinesses. Supply chain flexibility is developed from research by Angkiriwang et al. (2014), measured by 5 items, items measured on the Likert scale 5 points from 1 are totally disagree to 5 are totally agree.

Environment uncertainty: is the uncertainty of the business environment, the production environment, and the natural environment. Environment uncertainty was developed from the study of Fynes et al. (2004); Linn \& Maenhout (2019) and includes 5 modified items to suit the context of agricultural enterprises applying high technology in Vietnam. All items measured on a 5-point Likert scale from 1 strongly disagree to 5 are strongly agree.

Supply chain performance: Supply chain performance in high-tech agricultural enterprises in Vietnam. Supply chain performance was developed from Fynes et al. (2004) which includes 8 items in 4 aspects of flexibility, delivery, quality and cost. All items measured on a 5-point Likert scale from 1 strongly disagree to 5 are strongly agree.

Financial performance: The financial performance of high-tech agricultural enterprises, we inherited and developed from Le et al.'s research. (2019) and Phan et al. (2020). Financial performance is measured by 8 items on a 5-point Likert scale, from 1 strongly disagree to 5 is totally agree.

The research hypotheses are as follows:

$\mathrm{H}_{1}$ : Supply chain relationship quality has a positive impact on supply chain flexibility in high-tech agricultural businesses.

$\mathrm{H}_{2}$ : Supply chain relationship quality has a positive impact on supply chain performance in high-tech agricultural enterprises.

$\mathrm{H}_{3}$ : Environment uncertainty has a positive impact on supply chain relationship quality in agricultural enterprises applying high technology. 
$\mathrm{H}_{4}$ : Environment uncertainty has a positive impact on supply chain performance in agricultural enterprises applying high technology.

$\mathrm{H}_{5}$ : Supply chain performance has a positive impact on financial performance in agricultural enterprises applying high technology.

$\mathrm{H}_{6}$ : Environment uncertainty and technological innovation has a moderate role in the relationship between supply chain relationship quality and supply chain performance.

\subsection{Analytical techniques}

The collected data is cleaned of information, filtered the questionnaire, encoded and imported into statistical software SPSS 23.0 and Smart PLS 3.6. Next, we analyzed the data in the order of steps (1) Check the reliability of the scale with Cronbach Alpha coefficient, step (2) Explore discovery factor EFA, step (3) Check quantify the discriminant value, the appropriateness of the research model, step (4) Analyze the correlation between variables, step (5) Road analysis (path analysis) and multiple regression to test the hypotheses research. To analyze data after collection, we use excel to analyze data collection results through in-depth interviews. The results will be analyzed based on the frequency of occurrence of words, phrases. From there we built and examined constituents, observed variables and scales. To analyze survey data with detailed questionnaires, we used SPSS 23.0 and Smart PLS 3.6 to analyze the reliability of the scale, calculated differential validity, EFA and test hypotheses. We also used factor analysis to test the values of variables (Henseler et al. 2009, 2015). The reliability of the scale was tested by evaluating Cronbachs Alpha coefficient with an acceptable level of 0.6 (Hair et al., 2006). Variables with item-total correlation greater than 0.3 are accepted. If there are two observed variables with the Corrected Item - Total Correlation coefficient $<0.3$, we will remove them in the order of the observed variables with the smallest Corrected Item - Total Correlation. Cronbach's Alpha coefficient value level:

From 0.8 to close to 1 : very good measurement.

From 0.7 to nearly 0.8 : good measurement scale.

From 0.6 and above: eligible measurement scale (Hesenler et al., 2009, 2015).

Discovery factor analysis EFA will be based on Bartlett's or KMO values. The KMO value is appropriate if the value is greater than 0.6 (Henseler, 2009). Items of factor loadings need to be greater than 0.4 (Hair et al. 2017). Factor with an Eigen value of 1 or greater than 1 is usually retained (Henseler, 2009). To test research hypotheses, we use structural model analysis (Structural Equation Modeling, SEM) that has been commonly applied in domestic and foreign studies (Hair et al., 2006, 2011, 2014, 2017). The SEM model combines all techniques such as multivariate regression, factor analysis and mutual relationship analysis to allow testing of complex relationships in the research model.

\section{Research results}

The test results on SPSS 23 software show that all items have Cronbach Alpha coefficients greater than 0.7 and total variable correlation coefficients greater than 0.4 . Therefore, all items satisfy the condition of the reliability of the scale. Next, we conduct the validity assessment and explore factor analysis. KMO results from SPSS software gave a value greater than 0.5 at the $1 \%$ statistical significance level $($ Sig. $=0.000)$. Thus, all factors are satisfied to perform further analysis in Smart PLS 3.6 software. First, we evaluate the aggregate value from Table 1 as follows:

Table 1

Construct Reliability and Validity

\begin{tabular}{lcccc}
\hline & Cronbach's Alpha & rho_A & Composite Reliability & Average Variance Extracted (AVE) \\
\hline Adaptation & 0.911 & 0.911 & 0.911 & 0.672 \\
Co-operation & 0.872 & 0.873 & 0.873 & 0.695 \\
Communication & 0.898 & 0.898 & 0.898 & 0.638 \\
Enviromental uncertainty & 0.945 & 0.946 & 0.945 & 0.775 \\
Financial Performance & 0.947 & 0.951 & 0.947 & 0.645 \\
SC flexibility & 0.838 & 0.864 & 0.841 & 0.643 \\
SC performance & 0.920 & 0.921 & 0.920 & 0.696 \\
SC relationship quality & 0.957 & 0.971 & 0.961 & 0.525 \\
Technological innovation & 0.923 & 0.935 & 0.925 & 0.805 \\
Trust & 0.910 & 0.911 & 0.910 & 0.629 \\
\hline
\end{tabular}

The results from Table 1 show that all factors, pre-hidden variables have Cronbach's Alpha coefficients overall with values greater than 0.8 , all of which are excellent. In addition, all research variables have a value of Composite Reliability greater than 0.8 , thus ensuring reliability. Finally, the AVE value of the variables is greater than 0.5 with the minimum value being 0.525 . Next, we test the discriminant validity of latent variables in the research model as shown in Table 2 of the article. 
Table 2

Discriminant Validity (Fornell-Larcker Criterion)

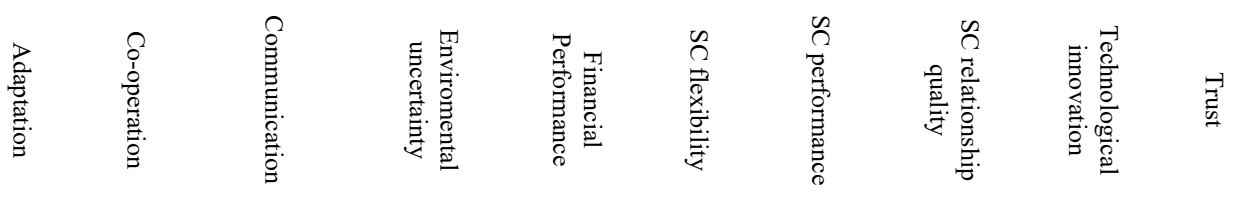

\begin{tabular}{|c|c|c|c|c|c|c|c|c|c|c|}
\hline Adaptation & 0.820 & & & & & & & & & \\
\hline Co-operation & 0.089 & 0.834 & & & & & & & & \\
\hline Communication & 0.010 & 0.081 & 0.799 & & & & & & & \\
\hline Enviromental uncertainty & 0.164 & 0.156 & 0.193 & 0.880 & & & & & & \\
\hline Financial Performance & 0.329 & 0.313 & 0.367 & 0.377 & 0.803 & & & & & \\
\hline SC flexibility & 0.182 & 0.153 & 0.239 & 0.351 & 0.334 & 0.802 & & & & \\
\hline SC performance & 0.450 & 0.496 & 0.470 & 0.237 & 0.139 & 0.223 & 0.834 & & & \\
\hline SC relationship quality & 0.023 & 0.003 & 0.037 & 0.284 & 0.368 & 0.230 & 0.484 & 0.725 & & \\
\hline Technological innovation & 0.478 & 0.451 & 0.527 & 0.285 & 0.417 & 0.245 & 0.489 & 0.500 & 0.897 & \\
\hline Trust & 0.020 & 0.192 & 0.049 & 0.172 & 0.326 & 0.197 & 0.474 & 0.037 & 0.463 & 0.793 \\
\hline
\end{tabular}

Table 2 shows that all values in the diagonal field of Table 2 are greater than the values in the table. The maximum value in the table has a value of 0.500 is also smaller than the minimum value on the diagonal of 0.725 , which means that the latent variables in the research model satisfy the condition of discriminant validity. Eligible for follow-up research.

Table 3

The results of R Square

\begin{tabular}{lcc}
\hline & R Square & R Square Adjusted \\
\hline Financial Performance & 0.390 & 0.389 \\
SC flexibility & 0.153 & 0.150 \\
SC performance & 0.422 & 0.415 \\
SC relationship quality & 0.658 & 0.659 \\
\hline
\end{tabular}

Table 3 shows that the R-Square value of the Financial performance variable is 39\%, which means that the variables in the research model explain 39\% of the variation of Financial performance, which is quite interesting. The R-square value of the supply chain performance is $42.2 \%$, nearly $50 \%$ of the variables in the research model explain $42.2 \%$ of the supply chain performance variation. At the end, the 4 aspects constituting supply chain relationship quality explain nearly $70 \%$ of the variation of this variable.

Table 4

The results of Fit Summary

\begin{tabular}{lcc}
\hline & Saturated Model & Estimated Model \\
\hline SRMR & 0.056 & 0.057 \\
d_ULS & 0.971 & 0.989 \\
d_G & 0.509 & 0.512 \\
Chi-Square & $1,627.002$ & $1,671.267$ \\
NFI & 0.881 & 0.887 \\
\hline
\end{tabular}

Model fit results show that the SRMR value is less than 0.06 , the NFI is greater than 0.88 so that the research model is suitable for the research data (Hair et al. 2017, 2011, 2013; Henseler et al. 2009, 2015). After analyzing the reliability and validity of the scales, as well as assessing the suitability of the model, we proceed to test research hypotheses in Fig. 2.

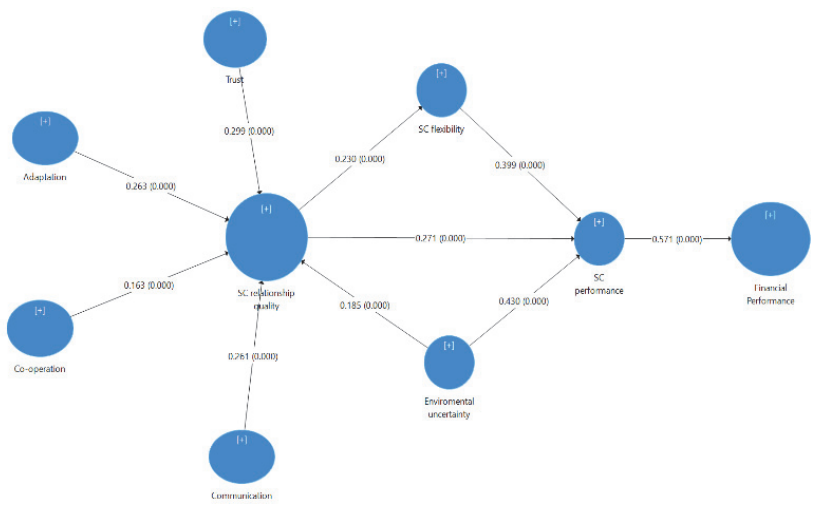

Fig. 2. Bootstrap results 
From the results in Fig. 2, the aspects that constitute supply chain relationship quality are statistically significant. Specifically, the Trust factor has the highest impact at the impact level of 0.299 at the $1 \%$ significance level $\left(\mathrm{P}_{-}\right.$value $=$ 0.000). The factor having the lowest impact on the second research variable - order factor supply chain relationship quality is the Co-operation factor at the 0.163 impact level at the significance level of $1 \%\left(\mathrm{P}_{-}\right.$value $\left.=0.000\right)$. The remaining 2 aspects, Adaptation and Communication, have a similar impact of 0.263 and 0.261 , both at $1 \%\left(P_{-}\right.$value $\left.=0.000\right)$. When the supply chain relationship quality research variable has the meaning of satisfying the conditions for performing hypothesis tests. The Bootstrap results in Fig. 2 shows, supply chain relationship quality has a very strong impact on supply chain performance with an impact coefficient of 0.271 at a significant level of $1 \%\left(P_{\text {_value }}=0.000\right)$. This means that for agricultural enterprises applying high technology, supply chain relationship quality plays an important role in supply chain performance. Supply chain relationship quality also had a fairly strong and positive impact on supply chain flexibility at an impact level of 0.230 at a significant level of $1 \%\left(P_{-}\right.$value $\left.=0.000\right)$. Supply chain flexibility has a strong impact on supply chain performance at an impact level of 0.399 at a $1 \%$ significance level $\left(\mathrm{P}_{-}\right.$value $\left.=0.000\right)$. This means that a supply chain is well adapted, demonstrating that its dynamics are good so according to resource-based theory, supply chain dynamics are now a special kind of resource. Making a difference for businesses in the value chain thereby significantly improving supply chain performance. Environment uncertainty has a strong positive impact on supply chain performance but only has a moderate positive impact on supply chain relationship quality at levels of 0.430 and 0.185 , respectively, and at the same $1 \%$ significance level $\left(\mathrm{P}_{-}\right.$value $\left.=0.000\right)$. Finally, supply chain performance has a very strong positive impact on financial performance at 0.571 with a significance level of $1 \%\left(\mathrm{P}_{-}\right.$value $\left.=0.000\right)$. This means that for high-tech agribusinesses, supply chain efficiency is a vital factor for high-tech agribusinesses. Because, the characteristic of agricultural enterprises is that the output produced depends a lot on the output of the product. For many years, Vietnamese agriculture suffers from a disease that "has a good harvest, a bad crop". The imbalance in supply and demand leads to the low efficiency of the agricultural sector. However, in agricultural enterprises applying high technology, the problem of supply chain relationship quality is solved more thoroughly, so the control of output and input is better and more stable. However, the Environment uncertainty factor still plays an important role in supply chain performance. The business environment is always uncertain and in agriculture depends on the uncertainty of the natural environment of the country of the seedlings, etc. Next, we examine the moderate role of Environment uncertainty and technologycial innovation in the relationship between supply chain relationship quality and supply chain performance. The test results are as follows:

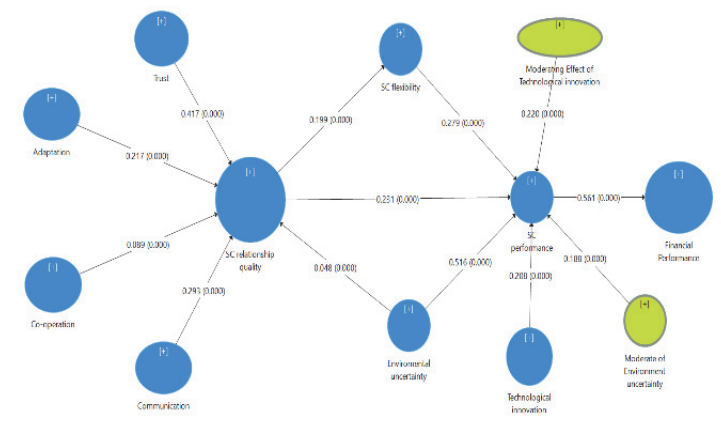

Fig. 3. Results of the moderate role test

From the results in Fig. 3, it shows that both Environment uncertainty and Technologycial innovation are statistically significant with impact coefficients of 0.188 and 0.220 respectively at the $1 \%$ significance level $\left(\mathrm{P}_{-}\right.$value $\left.=0.000\right)$. This means that Environment uncertainty and technological innovation has a role in regulating the relationship between supply chain relationship quality and supply chain performance. To test the level and direction of the impact of Environment uncertainty and technological innovation we use the impact coefficients and the following modeling:

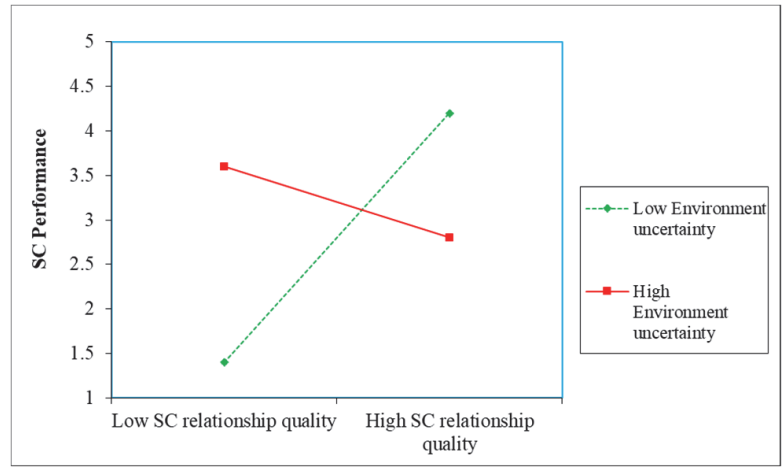

Fig. 4. Environment uncertainty moderate role

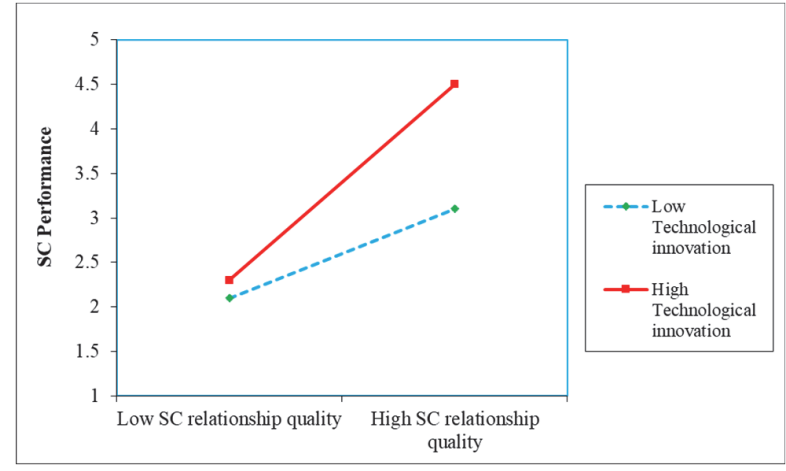

Fig. 5. The moderate role of Techonological innovation 
The analysis of the moderate impact mechanism of Environment uncertainty in the relationship between supply chain relationship quality and supply chain performance sshow that, with agricultural enterprises applying high technology, the more the impact of environment uncertainty, the higher the impact of the supply chain relationship quality to the supply chain performance. Because, in this case, the Environment uncertainty is almost uncontrollable by people, by the enterprise. Therefore, Environment uncertainty impacts not only the supply chain performance in particular but also it affects firm performance in general. When the environment is highly uncertain, there are great risks leading to the preventive and control activities not following normal rules, even the enterprises even suffer heavy losses. Therefore, in an environment with high uncertainty such as politics, weather, competitors, relationships in the value chain, the supply chain of the business makes the quality of these relationships slow and effective. In contrast, in a business environment where the lower the Environment uncertainty characteristic, the moderate and direct impact of the uncertain environmental factors will decrease and strengthen the impact of supply chain relationship quality on the supply chain. It can be explained that, in the business environment in which the Environment uncertainty is low, all business plans of the business can be controlled and have less risk. Then, with a good network of partners, the better the supply chain relationship quality, the closely linked links, so the supply chain performance is improved. From the results in Fig. 5, it shows that low technological innovation or high technological innovation increased the impact of supply chain relationship quality on supply chain performance. However, the higher the technological innovation, the more powerful the impact of supply chain relationship quality. The lower the enterprises that have technological innovation, the less the impact will be. The following is a summary of research hypotheses

Table 5

The results of Path Coefficients

\begin{tabular}{|c|c|c|c|c|c|}
\hline & $\begin{array}{c}\text { Original } \\
\text { Sample }(\mathrm{O})\end{array}$ & $\begin{array}{c}\text { Sample } \\
\text { Mean (M) }\end{array}$ & $\begin{array}{c}\text { Standard Deviation } \\
\text { (STDEV) }\end{array}$ & $\begin{array}{l}\text { T Statistics } \\
(|\mathrm{O} / \mathrm{STDEV}|)\end{array}$ & $\begin{array}{c}\mathrm{P} \\
\text { Values }\end{array}$ \\
\hline Adaptation $\rightarrow$ SC relationship quality & 0.263 & 0.261 & 0.007 & 35.153 & 0.000 \\
\hline Co-operation $\rightarrow$ SC relationship quality & 0.163 & 0.162 & 0.006 & 26.039 & 0.000 \\
\hline Communication $\rightarrow$ SC relationship quality & 0.261 & 0.262 & 0.006 & 40.529 & 0.000 \\
\hline Enviromental uncertainty $\rightarrow$ SC performance & 0.430 & 0.429 & 0.052 & 8.308 & 0.000 \\
\hline Enviromental uncertainty $\rightarrow$ SC relationship quality & 0.185 & 0.185 & 0.025 & 7.339 & 0.000 \\
\hline SC flexibility $\rightarrow$ SC performance & 0.399 & 0.398 & 0.052 & 7.634 & 0.000 \\
\hline SC performance $\rightarrow$ Financial Performance & 0.571 & 0.573 & 0.039 & 14.751 & 0.000 \\
\hline SC relationship quality $\rightarrow$ SC flexibility & 0.230 & 0.233 & 0.053 & 4.365 & 0.000 \\
\hline $\mathrm{SC}$ relationship quality $\rightarrow$ SC performance & 0.271 & 0.272 & 0.042 & 6.505 & 0.000 \\
\hline Trust $\rightarrow$ SC relationship quality & 0.299 & 0.299 & 0.010 & 31.432 & 0.000 \\
\hline
\end{tabular}

The above results have a certain confidence interval. The table belowTable 6 summarizes the confidence interval results of the research hypotheses.

Table 6

Confidence Intervals

\begin{tabular}{|c|c|c|c|c|}
\hline & Original Sample $(\mathrm{O})$ & Sample Mean (M) & $2.5 \%$ & $97.5 \%$ \\
\hline Adaptation $\rightarrow$ SC relationship quality & 0.220 & 0.226 & 0.149 & 0.312 \\
\hline Co-operation $\rightarrow$ SC relationship quality & 0.093 & 0.098 & 0.054 & 0.143 \\
\hline Communication $\rightarrow \mathrm{SC}$ relationship quality & 0.297 & 0.290 & 0.218 & 0.352 \\
\hline Enviromental uncertainty $\rightarrow$ SC & 0.125 & 0.125 & 0.014 & 0.233 \\
\hline SC flexibility $\rightarrow$ SC performance & 0.084 & 0.088 & -0.008 & 0.180 \\
\hline SC performance $\rightarrow$ Financial Performance & 0.504 & 0.505 & 0.422 & 0.578 \\
\hline SC relationship quality $\rightarrow$ Enviromental & 0.173 & 0.174 & 0.083 & 0.267 \\
\hline $\mathrm{SC}$ relationship quality $\rightarrow \mathrm{SC}$ flexibility & 0.188 & 0.190 & 0.100 & 0.276 \\
\hline $\mathrm{SC}$ relationship quality $\rightarrow$ SC performance & 0.403 & 0.404 & 0.311 & 0.488 \\
\hline Trust $\rightarrow$ SC relationship quality & 0.416 & 0.412 & 0.315 & 0.503 \\
\hline
\end{tabular}

\section{Conclusion}

Up to now, there are 29 hi-tech agricultural zones which have been put into operation, including: models of safe vegetable production, growing flowers and ornamental plants in Ho Chi Minh City, Bac Ninh, Lam Dong; farm-scale mushroom production in Vinh Phuc; tea growing areas based on the tea growing and processing technology of Taiwan (China) in Thai Nguyen, etc.

In order to improve operational efficiency for agricultural enterprises applying high technology and agricultural areas applying high technology, we recommend the following solutions:

1. Promote the initiative, eager to learn and test new things of farmers, in addition to policies to invest in technology, techniques, knowledge of cultivation and seeds for farmers. First of all, we must come from the needs, desires, ambitions and desires of the farmers, who make agricultural products for the society; plus, effective Government support. 
2. The decision to invest in high-tech agriculture will increase the contribution rate of agricultural science to production: The application of high technology in agriculture has not been given due attention; Therefore, the contribution of agricultural science to the growth of the industry is still very low (30\%) compared to the Netherlands and Taiwan, which is $80-90 \%$. MARD wants to increase this to $40-50 \%$ by 2020 , but the plan is not clear. This contribution only increases as high-tech agriculture develops.

3. Focused investment in the fisheries and livestock sector: The event that the Vietnam-Australia Group commenced the construction of a high-quality shrimp production complex in Bac Lieu (October 22, 2015) marked a new step in Vietnamese seafood, to raise high-tech super-intensive shrimp in greenhouses, with a total investment of more than 1,000 billion VND; When in operation, it created jobs for more than 2,000 people. This model will be a good lesson for HCMC.

4. Bringing information technology into the fruit and vegetable industry: lessons learned from RASA farm (Moc Chau), with a separate code to help consumers easily trace full information storage management software and the information about each type of vegetable, with over 40 types of vegetables, tubers and fruits. This is a new approach, consistent with international standards in Europe and Japan - fastidious markets, but very large amounts of imports.

5. To take advantage of ODA capital or build joint venture projects with large domestic and foreign enterprises, joint venture projects with the decisive content in current high-tech agricultural development. Because it is very capital intensive; Vietnamese farmers alone cannot stand it, and the progress will be very slow, the output market is not clear and full of risks.

These trends represent a series of challenges facing food and agriculture. High input and resource-intensive farming systems have caused massive deforestation, water scarcity, land depletion and high greenhouse gas emissions, unable to provide sustainable food.

Eradicating extreme poverty, and ensuring that vulnerable people are not caught in poverty, requires action to reduce inequality. That means addressing inequalities between and within the country, in terms of income, in opportunities and in property rights, including land. Pro-poor growth strategies, ensuring that the weakest engage the benefits of market integration and invest in agriculture, increase their rural incomes and investment opportunities and address the root causes of migration. But pro-poor growth must move beyond agriculture, by engaging in both urban and rural areas and support job creation and income diversification. Social protection combined with pro-poor growth will help meet the challenge of ending hunger and address the three-part burden of malnutrition through a healthier diet. Permanently eradicating extreme hunger, malnutrition and poverty requires building resilience to crises, natural disasters and protracted conflicts, and preventing conflict by promoting global development and equity. Food system review and management are needed to meet current and future challenges. The food systems are organized vertically, providing standard food for urban areas and formal employment opportunities. But they need to go hand in hand with responsible investments and considerations for the livelihoods of smallholder farmers, an environmental footprint of extended food supply chains and the impact on biodiversity. These concerns need to be addressed by making food systems more efficient, comprehensive and flexible.

According to the report, Vietnam invests in agricultural research and development equivalent to $0.2 \%$ of agricultural GDP, while in developed countries this rate is 3-5 times or even 10 times higher. Therefore, in order for the agricultural sector to develop quickly and sustainably, affirm the brand value, products need to strengthen human resources for research, at the same time, promot the application and transfer of technology to adapt to climate change, ecological agriculture along with promoting investment attraction and high-tech zones. To step up the incubation of hi-tech enterprises and high-tech fields, the Government also needs to focus on building a national key program on the Fourth Industrial Revolution. Along with that, there is a need to continue to build and develop a contingent of science and technology staff, focusing on attracting Vietnamese intellectuals abroad, paying attention to develop national innovation startups to promote creative entrepreneurship in the community, especially the young generation.

Recently, Vietnam's agriculture has developed quite comprehensively and is moving towards large commodity production, with increasing productivity and quality, ensuring food security and sustainable poverty reduction. In addition, the agricultural product market has had a new development with many agricultural products having a high position in the international market. Vietnamese agricultural products are present in over 180 countries and territories, including major markets such as the US, Japan, EU. The successes and outstanding development of the agricultural sector have contributed to agriculture and rural development, in which the main focus is on high-tech agricultural development. In order for agriculture to have high productivity and good quality, there are 6 factors that impact as follows:

Firstly, it is a good breed. Therefore, it is necessary to have hybrid or genetic modification technology to create good varieties (such as seedless grapes or flat seed durian), high yield and resistant to pests and diseases. The US is currently the world leader in seed technology.

Second, the fertilizer must be good, it must be able to produce many different types of fertilizer: the foliar fertilizer, the root fertilizer and suitable for different plants, suitable for different growth periods of the plant. Currently, the Netherlands is the world leader in fertilizers for crops. 
Third, pesticides have to be good. An insecticide that can kill harmful pests and diseases must be created without killing other species. At the same time, it is not harmful to humans as well as to the trees. In general, all vegetables are pests, so there are countless different types of pesticides. America is still the leading country in the world in this field.

Fourth, the soil should be good. This is about understanding different soil types that are suitable for different plants. In general, "this dish", farmers are good everywhere. The only difference is that in the US or other countries they buy land and mix compost and appropriate ingredients and then spread them to plant, not improve the soil like Vietnam.

Fifth, the water must be good. However, in the desert water is expensive and rare, so Israel invented drip irrigation. In Vietnam, watering with a hose or watering by hand is comfortable.

Sixth, to be knowledgeable about the growth cycle of plants. In general, this technologist often steals books to farmers, the only difference is that they synthesize and make training materials clearer.

\section{Acknowledgement}

This research was funded by Vietnam National Foundation for Science and Technology Development (NAFOSTED) under grant number 502.02-2015.14

\section{References}

Angkiriwang, R. I., Pujawan, N., \& Santosa B. (2014) Managing uncertainty through supply chain flexibility: reactive vs. proactive approaches, Production \& Manufacturing Research, 2(1), 50-70.

Bhatnagar, R., \& Sohal, A.S. (2005) Supply chain competitiveness: measuring the impact of location factors, uncertainty and manufacturing practices. Technovation, 25(5), 443-456

Carter, C.R., Meschnig, G., \& Kaufmann, L. (2015) Moving to the next level: why our discipline needs more multilevel theorization. Journal Supply Chain Management, 51(4), 94-102

Chaudhuri, A., Dukovska-Popovska, I., Damgaard, C. M., \& Hvolby, H. H. (2014, September). Supply uncertainty in food processing supply chain: sources and coping strategies. In IFIP International Conference on Advances in Production Management Systems (pp. 183-191). Springer, Berlin, Heidelberg.

Davis, T (1993) Effective supply chain management. Sloan Management Review, 34(4), 35-46

Economic, R. (2007). Supply Chain Flexibility. Review Literature And Arts Of The Americas, 2(1), 1-84

Fynes, B., de Búrca, S., \& Marshall, D. (2004). Environmental uncertainty, supply chain relationship quality and performance. Journal of Purchasing and Supply Management, 10(4-5 SPEC. ISS.), 179-190.

Granovetter, M. (1992). Economic institutions as social constructions: a framework for analysis. Acta Sociologica 35, 311.

Hair, J.F., Ringle, C.M., \& Sarstedt, M. (2011). PLS-SEM: in deed a silver bullet, Journal of Marketing Theory and Practice, 19(2), 139-151.

Hair, J.F., Hult, G.T.M., Ringle, C., \& Sarstedt, M. (2013). A Primer on Partial Least Squares Structural Equation Modeling (PLS-SEM), Sage Publications Ltd, London.

Hair, J.F., Henseler, J., Dijkstra, T., Sarstedt, M., Ringle, C., Diamantopoulos, A., Straub, D., Ketchen, D., GTM, H., \& Calantone, R. (2014). Common beliefs and reality about partial least squares: comments on Rönkkö and Evermann, Organizational Research Methods, 17(2), 182-209.

Hair, J. F., Hult, G. T. M., Ringle, C. M., \& Sarstedt, M. (2017). A Primer on Partial Least Squares Structural Equation Modeling (PLS-SEM), 2nd Ed., Sage: Thousand Oaks.

Henseler, J., Ringle, C.M. and Sarstedt, M. (2015). A new criterion for assessing discriminant validity in variance-based structural equation modeling, Journal of the Academy of Marketing Science, 43(1), 115-135.

Henseler, J., Ringle, C.M. and Sinkovics, R.R. (2009). The use of partial least squares path modeling in international marketing, in Sinkovics, R.R. and Ghauri, P.N. (Eds), New Challenges to International Marketing, Emerald Group Publishing Limited.

Karami, M., Ghasemi, R., Khan, S., Bakar, A., Hamid, A., Karami, M., \& Fm, M. (2014). Market orientation and supply chain innovation relationship: Conceptual Framework Model, 21(9), 1526-1532.

Kleindorfer, P.R., \& Saad, G.H. (2005) Managing disruption risks in supply chains. Production and Operation Research Society, 54(5), 507-514

Lee, H.L. (2002) Aligning supply chain strategies with product uncertainties. California Management Review, 44(30), 105119

Lee, S.M., Tae Kim, S., \& Choi, D. (2012). Green supply chain management and organizational performance. Industrial Management and Data Systems, 112(8), 1148-1180.

Le, T. T, Nguyen, T. A., Phan, T. T. H., Tran, M. D., Phung, X. T., Tran, T. T., \& Giao K. N. (2019). Impact of corporate social responsibility on supply chain management and financial performance in Vietnamese garment and textile firms. Uncertain Supply Chain Management, 7(3), 679-690.

Li, S., Ragu-Nathan, B., Ragu-Nathan, T. S., \& Rao, S. S. (2006). The impact of supply chain management practices on competitive advantage and organizational performance. Omega, 34(2), 107-124.

Lin, C., Kuei, C. \& Chai, K., (2013). Identifying critical enablers and pathways to high performance supply chain quality management. International Journal of Operations \& Production Management. 33(3), 347-370. 
Merschmann, U., \& Thonemann, U. W. (2011). Supply chain flexibility, uncertainty and firm performance: An empirical analysis of German manufacturing firms. International Journal of Production Economics, 130(1), 43-53.

Miller, K.D. (1993) Industry and country effects on managers' perceptions of environmental uncertainties. Journal of International Bussiness Studies, 24(4), 693-714

Min, H., \& Galle, W.P. (2001), Green Purchasing Practices of US Firms, International Journal of Operations and Production Management, 21(9), 1222-1238.

Narasimhan, R., Jayaram, J., 1998. Causal linkages in supply chain management: an exploratory study of North American manufacturing firms. Decision Sciences 29(3), 579-605.

Neely, A., Gregory, M., \& Platts, K. (1991). Performance measurement system design: a literature review and research agenda. International Journal of Operations and Production Management, 15(4), 80-116

Phan, T. T. H., Doan, X. T., \& Nguyen, T. T. T. (2019). The impact of supply chain practices on performance through supply chain integration in textile and garment industry of Vietnam. Uncertain Supply Chain Management, 8(1), 175186.

Prater, E. (2005). A framework for understanding the interaction of uncertainty and information systems on supply chains. International Journal of Physical Distribution and Logistics Managent, 35(7), 524-539.

Patil, D.P., Shrotri, A.P., \& Dandekar, A.R. (2012). Management of uncertainty in supply chain. International Journal of Emerging Technolgy and Advanced Engineering, 2(5), 2250- 2459.

Robicheaux, R.A., \& Coleman, J.E. (1994). The structure of marketing channel relationships. Journal of the Academy of Marketing Science, 22(1), 38-51.

Shen, L., Olfat, L., Govindan, K., Khodaverdi, R., \& Diabat, A. (2013). A fuzzy multi-criteria approach for evaluation green suppliers' performance in green supply chain with Luiguistic preferences. Resour Conserv Recycl, 74, 170-179.

Simangunsong, E., Hendry, L.C., Stevenson, M. (2011) Supply-chain uncertainty: a review and theoretical foundation for future research. International Journal of Production Research, 50(16), 4493-4523.

Stevenson, M., \& Spring, M. (2007). Flexibility from a supply chain perspective: definition and review.

Tang, C. S. (2006). Perspectives in supply chain risk management. International Journal of Production Economics, 103, 451-488.

Thongrattana, P.T., \& Jie, F. (2009) Identifying sources of perceived environmental uncertainty along Thai rice supply chain. Paper presented on the 3rd international conference on operations and supply chain Management, Malaysia: OSCM

Wang, L., Yeung, J. H. Y., \& Zhang, M. (2011). The impact of trust and contract on innovation performance: The moderating role of environmental uncertainty. International Journal of Production, 2(8), 21-38

Uzzi, B. (1997). Social structure and competition in interfirm networks: the paradox of embeddedness. Administrative Science Quarterly, 36, 35-67.

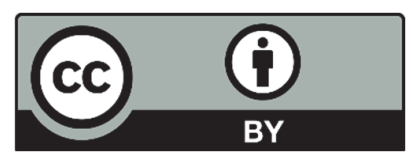

(C) 2020 by the authors; licensee Growing Science, Canada. This is an open access article distributed under the terms and conditions of the Creative Commons Attribution (CC-BY) license (http://creativecommons.org/licenses/by/4.0/). 